\title{
Toxic effects of alloxan in the rat. Mechanism and protection with Zinc.
}

\author{
Sohair A. Moustafa \\ Department of Zoology, Faculty of Science Suez Canal University, \\ Ismailia, Egypt.
}

\begin{abstract}
In the present study male albino rats weighing $200 \pm 50 \mathrm{~g}$ were made diabetic by injection with a single ip dose of alloxan $(100 \mathrm{mg} / \mathrm{kg})$. Another group of rats was simultaneously treated with alloxan $(100 \mathrm{mg} / \mathrm{kg})$ and a single ip dose of zinc chloride $\left(\mathrm{ZnCl}_{2}\right)(5 \mathrm{mg} / \mathrm{kg})$. Blood and tissue samples were collected at 24, 48 and 72 hours posttreatment in both groups. Plasma insulin was significantly higher than control 24 hours after treatment in both alloxan and alloxan plus $\mathrm{Zn}$ treated groups, and then decreased 48 and 72 hours post treatment in both groups. The reduction was significant after 72 hours in alloxan treated group. A reduction in pancreatic glutathione (GSH) concentration was observed in alloxan-treated rats compared with control values at all sampling times of the experiment. When alloxan and $\mathrm{ZnCl}_{2}$ were administered simultaneously, alloxan-induced reduction in pancreatic GSH was diminished, and a significant high GSH values were recorded relative to those recorded after treatment with alloxan alone 24, 48 and 72 hours post treatment. Alloxan has induced a significant increase in the serum levels of creatinine, urea and blood urea nitrogen (BUN), 24 hours after treatment, which returned nearly to their normal levels 48 and 72 hours after alloxan injection except for the levels of urea and blood urea nitrogen (BUN) which were dramatically declined 48 hours after treatment before its return to the control level 72 hours following alloxan intoxication. The concentrations of serum metabolites were unchanged due to the simultaneous treatment with alloxan and $\mathrm{ZnCl}_{2}$ as compared to their concentrations in alloxan alone-treated rats except after 48 hours where alloxan plus $\mathrm{Zn}$ treatment has caused a significant elevation in the serum levels of urea and BUN relative to their values in alloxan alone-treated rats. A significant increase in liver glycogen level was observed 24 hours after alloxan and alloxan plus $\mathrm{Zn}$ treatments. Afterwards, it was markedly depleted by the two treatments 48 and 72 hours post treatment. The current results clearly indicate that the deleterious effects of alloxan were attenuated at many points by the simultaneous treatment with $\mathrm{Zn}$. Of special importance was the effect of $\mathrm{Zn}$ in lowering the blood glucose concentration and replenishing the pancreatic GSH content.
\end{abstract}

Key words: Alloxan; Zinc; Diabetes; Rats.

\section{Introduction}

There is evidence that oxidative stress, defined as a persistent imbalance between the production of highly reactive molecular species (chiefly 
oxygen and nitrogen) and antioxidant defense, leads to tissue damage (Rosen et al., 2001)

Oxidative stress is implicated in a broad variety of chronic and acute diseases, including such age-related diseases as diabetes (Oh-Ishi, et al., 2003 and Varvarovska, et al., 2003). There is data indicating that reactive oxygen species (ROS) formation is a direct consequence of hyperglycemia (Brownlee, 2001); more recent studies have suggested that increased free fatty acids (FFA) levels may also result in ROS formation (Bakker et al., 2000). Because of their ability to directly oxidize and damage DNA, protein and lipid, ROS are believed to play a direct key role in the pathogenesis of late diabetic complications (Nishikawa et al., 2000; West, 2000 and Rosen et al., 2001). Actually, there is considerable amount of data indicating that the chronic elevation of plasma glucose causes many of the major complications of diabetes, including nephropathy, neuropathy, and macro-and microvascular damage (DeFronzo, 1997; Schmeichel, et al., 2003; Agarwal, et al., 2002; Mychka, et al., 2002 and Ramana et al., 2002).

In addition to their ability to directly inflict damage on macrom olecules, ROS and reactive nitrogen species (RNS) indirectly induce damage to tissues by activating a number of cellular stress-sensitive pathways. Activation of these pathways results in the increased expression of numerous gene products that also cause cellular damage and play a major role in the etiology of the late complications of diabetes (Marshall et al., 1991; Kyriakis and Avruch, 1996 and Barnes \& Karin, 1997).

It has been proposed that the hyperglycemia-induced, and possibly FFA-induced, activation of stress pathways plays a key role in the development of not only the late complications in type 1 and type 2 diabetes, but also the insulin resistance (Marshall et al., 1991; Boden et al., 1994 and Schleicher and Weiger, 2000) and impaired insulin secretion seen in type 2 diabetes (Evans et al., 2003).

Although the understanding of how hyperglycemia-induced oxidative stress ultimately leads to tissue damage has advanced considerably in recent years (Poitout et al., 2002; Brownlee, 2001; Koya \& King, 1998 and Nadler \& Natarajan, 2000), te effective therapeutic strategies to prevent or delay the development of this damage remain limited. At this juncture, the general use of antioxidants could be a reasonable approach to reduce oxidative stress in diabetes. Actually many studies have addressed the importance of many types of antioxidants in the protection against the development of diabetic consequences (Mizushige et al., 2002; Agardh et al., 2002; Kocic et al., 2002 and Ayaz et al., 2002). The best treatment of diabetes and its complications remains the prevention of ROS and RNS generation through strict glycemic control.

Accumulating evidence indicates that zinc is a fundamental element for maintenance of the structural and functional integrity of cells and tissues e.g. (Rudolf et al. 2001). Because of its ability as a free radical scavenger and a biological membrane stabilizer, nume rous studies were designed to explore the protective role of $\mathrm{Zn}$ in many free radicals initiating systems (Hanna et al., 1993, Moustafa et al., 2000, Moustafa, 2001 and Moustafa, 2003). Moreover, recent studies have reported the beneficial effect of antioxidants and zinc supplementation in restraining the progression to advanced age-related macular degeneration (Evans 2002), and 
in the protection against cancer (Provinciali, et al., 2002).

The current study was undertaken to through more light on the mechanisms of alloxan cytotoxicity and to clarify the possible protection with $\mathrm{Zn}$ in alloxan-diabetic rats. Thus the possible involvement of $\mathrm{Zn}$ in therapeutic strategies that aims to interrupt the stress sensitive pathways mediating diabetic complications.

\section{Materials And Methods}

Male albino rats weighing $200 \pm$ $50 \mathrm{~g}$ (6-9 months) were obtained from the animal house of the Zoology Department, Faculty of Science, Suez Canal University. Rats were raised on a standard chow mix and allowed access to food and water ad libitum. The animals were randomly assigned into three groups: (a) a control received the vehicle used for alloxan and $\mathrm{ZnCl}_{2}(0.9$ $\%$ saline). At least five rats were sacrificed at 0, 24, 48 and 72 hours after vehicle administration. (b) Alloxantreated group that received a single ip dose $(100 \mathrm{mg} / \mathrm{kg}$ ) (McDowell, et al. 1994). Five rats were sacrificed at 24 , 48 and $72 \mathrm{hr}$ after alloxan treatment. (c) Alloxan plus zinc chloride $\left(\mathrm{ZnCl}_{2}\right)$ treated group which received a single. ip dose $(100 \mathrm{mg} / \mathrm{kg})$ together with a single ip dose of $\mathrm{ZnCl}_{2}(5 \mathrm{mg} / \mathrm{kg})$ ( Moustafa, 2001). Five rats were sacrificed with the same schedule as group b.

At the required times, blood samples were obtained from lightly anesthetized rats with ether from the orbital sinus and serum was prepared and frozen at -20 until the time of assay. After blood sample collection, the rats were killed by decapitation and the pancreases and livers were rapidly excised, rinsed in saline, blotted and weighed.

\section{Determination of serum metabolites}

Serum samples used for the determination of the level of glucose, urea, blood urea nitrogen (BUN) and creatinine were analyzed by the staff of the Clinical Pathology Laboratory in the Faculty of Medicine, Suez Canal University using Hetachi 704 auto analyzer.

Plasma insulin was measured using the insulin radioimmunoassay kit with human insulin as a standard.

Estimation of pancreatic glutathione

Pancreatic glutathione was estimated according to the method of Tieze (1969).

\section{Determination of liver glycogen}

Liver glycogen was determined according to the method of Roe (1955).

\section{Statistical analysis}

One way ANOVA followed by Duncan's multiple range test were used for data analysis. Statistica was the software used for the analysis. Accepted level of significance $\mathrm{p} \leq 0.05$.

\section{Results}

\section{Serum glucose and insulin levels in alloxan and alloxan plus $\mathbf{Z n C l}_{2}$. treated-rats}

Alloxan treatment induced a significant elevation in serum glucose levels at any time of the experiment when compared with controls receiving vehicle (Table 1). The treatment with alloxan and $\mathrm{ZnCl}_{2}$ inhibited the increase in blood glucose at all times in the experiment. Meanwhile, a significant elevation in serum insulin was observed 24 hours following treatment in both alloxan and alloxan plus Zn-treated groups. Afterwards, serum insulin concentrations were significantly reduced below control levels 48 and 72 hours in both alloxan and alloxan $+\mathrm{Zn}$ treated groups (Table 1). 
Effect of alloxan and alloxan plus $\mathrm{ZnCl}_{2}$ treatments on pancreatic Glutathion (GSH) content

A reduction in pancreatic GSH concentration was observed in alloxantreated rats compared with control values at any time of the experiment. This decrease was significant 48 and 72 hours post treatment (fig. 1). When alloxan and $\mathrm{ZnCl}_{2}$ were administered simultaneously, alloxan-induced reduce -tion in pancreatic GSH was diminished, and a significant increase in this parameter was seen relative to treatment with alloxan alone 24, 48 and 72 hours after treatment (fig. 1).

Effect of alloxan and alloxan plus $\mathrm{ZnCl}_{2}$-treatment on serum metabo lites

Fig. 2 represents the time-dependent changes in serum metabolites after ip injection of alloxan and alloxan plus $\mathrm{ZnCl}_{2}$. The serum levels of creatinine, urea and BUN were significantly elevated 24 hours following alloxan treatment. A dramatic reduction in serum urea and BUN was observed 48 hours after alloxan administration and returned nearly to the control level 72 hours post treatment. The serum levels of creatinine returned nearly to the normal level 48 and 72 hours after alloxan treatment. Alloxan plus $\mathrm{ZnCl}_{2^{-}}$ treatment had no significant effect on the changes induced by alloxan alone treatment on these parameters except for urea and $\mathrm{BUN}$, where $\mathrm{ZnCl}_{2}-$ treatment caused a significant increase in their levels relative to their levels in alloxan alone-treated rats 48 hours after treatment. The calculated BUN/ creat inine $(B / C)$ was unchanged following both treatments except after 48 hours of alloxan treatment where it was significantly reduced compared to the control value and remained low in the alloxan plus $\mathrm{ZnCl}_{2}$-treated group.

\section{Effect of alloxan and alloxan plus $\mathbf{Z n C l}_{2}$-treatment on liver glycogen}

Liver glycogen content showed an initial and a significant increase 24 hours after both alloxan and alloxan plus $\mathrm{ZnCl}_{2}$-treatments. Afterwards, it was markedly depleted by the two treatments 48 and 72 hours post treatment (fig. 3).

Table 1. Time-dependent changes in serum glucose and insulin levels after a single ip injection of alloxan $(100 \mathrm{mg} / \mathrm{kg}$ )(Alloxan group) or after injection of alloxan (100 $\mathrm{mg} / \mathrm{kg}$ ) plus $\mathrm{ZnCl}_{2}(5 \mathrm{mg} / \mathrm{kg})$ (Alloxan $+\mathrm{Zn}$ group).

\begin{tabular}{|c|c|c|c|c|c|c|c|c|c|}
\hline & \multicolumn{9}{|c|}{ Time after treatment } \\
\hline & \multicolumn{3}{|c|}{24 hours } & \multicolumn{3}{|c|}{48 hours } & \multicolumn{3}{|c|}{72 hours } \\
\hline & Control & Alloxan & $\begin{array}{c}\text { Alloxan } \\
+\mathrm{Zn} \\
\end{array}$ & Control & Alloxan & $\begin{array}{l}\text { Alloxan } \\
+\mathrm{Zn}\end{array}$ & Control & Alloxan & $\begin{array}{l}\text { Alloxan } \\
+ \text { Zn }\end{array}$ \\
\hline $\begin{array}{l}\text { Glucose } \\
\text { (mg/dl) }\end{array}$ & $\begin{array}{l}99 \\
\pm 9.61\end{array}$ & $\begin{array}{l}180.766 * \\
\pm 15.88\end{array}$ & $\begin{array}{l}118.8 * * \\
\pm 5.2\end{array}$ & $\begin{array}{l}104.133 \\
\pm 11.19\end{array}$ & $\begin{array}{l}454.3 * \\
\pm 68.49\end{array}$ & $\begin{array}{l}237.23 * * \\
\pm 16.25\end{array}$ & $\begin{array}{l}107.063 \\
\pm 7.94\end{array}$ & $\begin{array}{l}787.6 * \\
\pm 84.61\end{array}$ & $\begin{array}{l}433.03 .667 * * \\
\pm 88.595\end{array}$ \\
\hline $\begin{array}{l}\text { Insulin } \\
(\mu \mathrm{U} / \mathrm{ml})\end{array}$ & $\begin{array}{l}21.123 \\
\pm 1.56\end{array}$ & $\begin{array}{l}55.587 * \\
\pm 7.693\end{array}$ & $\begin{array}{l}51.433 \\
\pm 5.932\end{array}$ & $\begin{array}{l}19.89 \\
\pm 1.418\end{array}$ & $\begin{array}{l}17.717 \\
\pm 0.857\end{array}$ & $\begin{array}{l}19.0067 \\
\pm 1.42\end{array}$ & $\begin{array}{l}22.358 \\
\pm 1.563\end{array}$ & $\begin{array}{l}9.033^{*} \\
\pm 2.99\end{array}$ & $\begin{array}{l}11.50 \\
\pm 1.276\end{array}$ \\
\hline
\end{tabular}

Results are represented as the means \pm SE of five animals. $* \mathrm{P} \leq 0.05$ control group versus alloxan group; ${ }^{* *} \mathrm{P} \leq 0.05$ alloxan group versus alloxan $+\mathrm{Zn}$-group. 

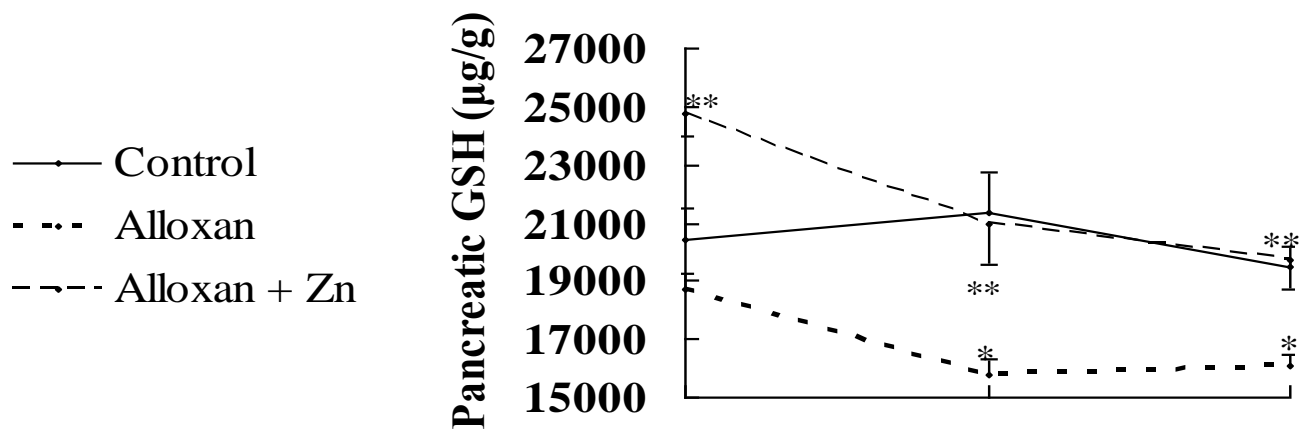

$24 \mathrm{hr}$

$48 \mathrm{hr}$

$72 \mathrm{hr}$

\section{Post-treatment time (hours)}

Figure 1. Pancreatic glutatione (GSH) in control rats, alloxan-treated rats and alloxn plus $\mathrm{ZnCl} 2$-treated rats. Results are represented as the means $\pm \mathrm{SE}$ of five animals. * $\mathrm{P} \leq 0.05$ control group versus alloxan group; ** $\mathrm{P} \leq 0.05$ alloxan group versus alloxan plus $\mathrm{ZnCl} 2$-treated group.
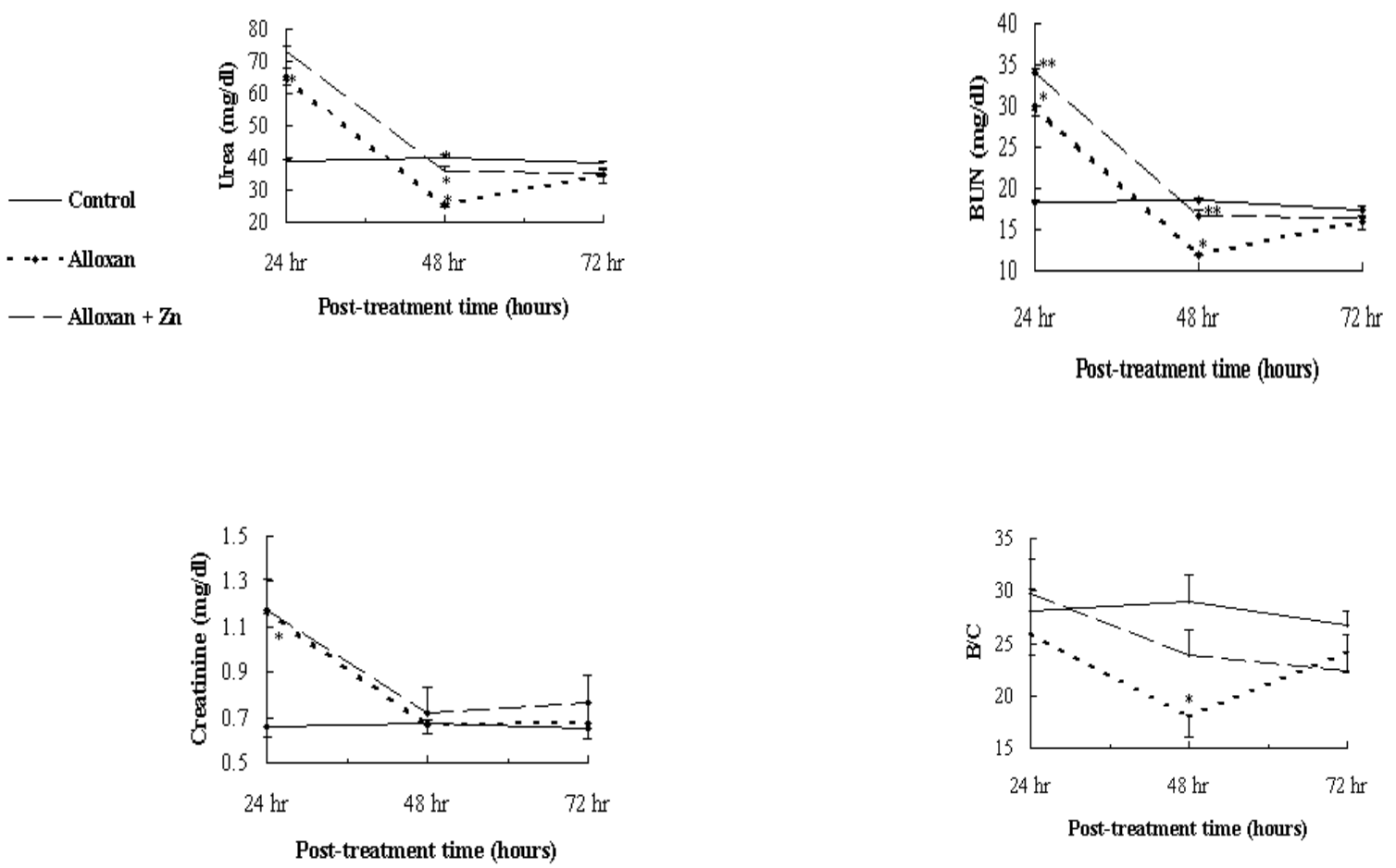

Figure 2. Serum metabolities: urea, blood urea nitrogen (BUN), creatinine and blood urea nitrogen/creatinine ratio $(\mathrm{B} / \mathrm{C})$ in control rats, alloxan-treated rats and alloxan plus $\mathrm{ZnCl} 2$-treated rats. Results are represented as the means $\pm \mathrm{SE}$ of five animals. $* \mathrm{P} \leq 0.05$ control group versus alloxan group; ** $\mathrm{P} \leq 0.05$ alloxan group versus alloxan plus $\mathrm{ZnCl} 2$-treated group. 

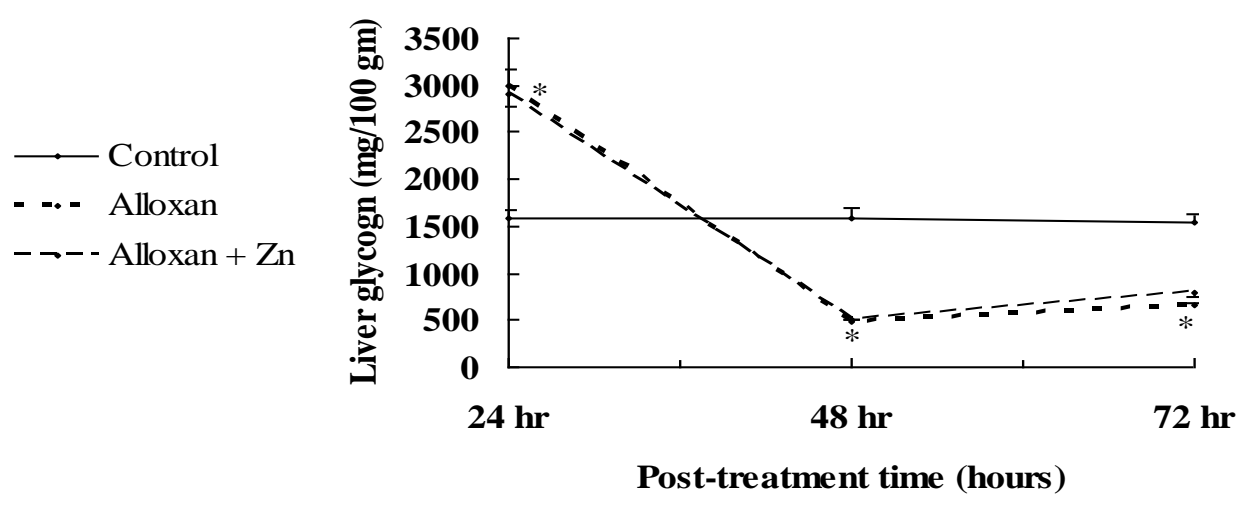

Figure 3. Liver glycogen in control rats, alloxan-treated rats and alloxn plus $\mathrm{ZnCl}$ treated rats. Results are represented as the means \pm SE of five animals. $* \mathrm{P} \leq$ 0.05 control group versus group versus alloxan group; ** $\mathrm{P} \leq 0.05$ alloxan group versus alloxan plus $\mathrm{ZnCl} 2$-treated group.

\section{Discussion}

The present data indicate an initial rise in serum insulin $24 \mathrm{hrs}$ after alloxan treatment which could be attributed to the peroxidative damage caused by alloxan on the cell membranes of pancreatic cells and the release of the stored insulin into the circulation. The existence of hyperglycemia in the presence of hyperinsulinaemia that is observed 24 hours after alloxan treatment could be interpreted by the development of insulin resistance induced by alloxan. Alloxan may disturb the redox status of cells other than pancreatic cells, which are targets of insulin action. In these cells, the cellular membranes may also be subjected to the peroxidative damage of ROS generated by alloxan. Alloxaninduced enhancement of tissue lipid peroxidation has previously been reported (Stefek \& Tmkova,1996 and Moustafa, 2003). These effects may cause the impairment of glucose transport across the cell membrane as well as the impairment of the more distal intracellular glucose metabolism steps. In combination, these effects would eventually lead to insulin resistance at the cellular level in alloxan-intoxicated rats. The impairment of glucose transport across the cell membrane was suggested to be a major mechanism behind the development of glucose intolerance in aged rats (Moustafa et al., 1995). Moreover, The glucose transport was reported to be the rate limiting step for the overall glucose metabolism in muscle (Elbrink, and Bihler, 1975). Indeed, the study of Ader et al. (1998) has presented an evidence for direct action of alloxan to induce insulin resistance at the cellular level. Therefore, it can be assumed that the development of hyperglycemia in alloxan-treated rats is due to multiple factors including not only the impaired capacity of the insulin synthesizing cells of the pancreas but also to the insulin resistance in other cells that are targets to insulin action. Additionally, it has been reported that in type 2 diabetes there is a poor response of the pancreatic cells to the glycemic effect (Sempoux et al., 2001). 
The toxic actions of alloxan are thought to be caused by the hydroxyl radical $\left(\mathrm{OH}^{+}\right)$generated in a cyclic reaction involving alloxan and its reduction product, alloxan radical $\left(\mathrm{HA}^{+}\right)$(Sakurai and Ogiso, 1994). Moreover, pancreatic beta-cells exposed to hyperglycemia produce reactive oxygen species (ROS) (Sakurai and Ogiso, 1994). Because beta-cells are sensitive to oxidative stress, excessive ROS may cause dysfunction of betacells (Sakurai and Ogiso, 1994). Thus, oxidative stress appears to account for the depletion of pancreatic GSH that is seen in alloxan diabetic rats. Previously the study of Moustafa (1998) suggested that GSH depletion is the mechanism underlying glucose intolerance in allyl alcohol-treated rats. The depletion of pancreatic GSH may disturb the redox status in pancreatic cells. Considerable evidence indicates that maintenance of protein redox status is of fundamental importance for cell function, whereas structural changes in proteins are considered to be among the molecular mechanisms leading to diabetic complications (Altomare et al. 1997). Additionally, maintenance of the redox potential of the cell was reported to be an essential condition for maintaining its synthetic capacity (Hazelton and Lang, 1983). Accordingly, alloxaninduced GSH depletion in the pancreatic cells may impair insulin synthesis. This may account for the observed reduction of plasma insulin level seen 48 and 72 hours following alloxan treatment. This could be attributed to impaired insulin synthesis in the pancreatic islets and/or the severe destruction of the pancreatic cells. Actually the study Buko et al. (1996) reported a decrease in the number of pancreatic islets and beta/alpha cell ratio in alloxan-diabetic rats. Moreover, the study of (Paolisso, et al., 1992) indicates that in both normal individuals and in type 2 diabetic patients, restoration of redox balance by infusion of glutathione improves insulin sensitivity along with $ß$-cell function.

Many studies have addressed the importance of antioxidants for the control of the abnormalities in diabetes (Mizushige et al., 2002; Agardh et al., 2002; Kocic et al., 2002 and Ayaz et al., 2002). The current results show that $\mathrm{Zn}$ treatment of alloxan-diabetic rats resulted in the elevation of pancreatic GSH and the inhibition of the increase in plasma glucose of these rats. The mechanism of $\mathrm{Zn}$ protection against oxidative damage may lie in its ability to bind and stabilize cellular and subcellular membranes against lipid peroxidation and disintegration (Thomas et al. 1986). Zn treatment was reported to reduce lipid peroxidation in the retinas and livers of alloxan-treated rats (Moustafa, 2003) and in the livers of allyl alcohol-treated rats (Moustafa, 2001). The protective effect of $\mathrm{Zn}$ against lipid peroxidation (of cellular and subcellular membranes) may reverse the impairment in glucose transport and glucose metabolism in the cells of alloxan-diabetic rats. $\mathrm{Zn}$ was also found to induce metallothionein (MT) synthesis (Hanna, et al., 1993). The high sulfhydryl content enables MT to efficiently scavenge oxy-radicals (Thornalley \& Vasak, 1985 and Sunters \& Lui, 1990). Another possible protective mechanism of MT is its ability to release $\mathrm{Zn}$ for binding at sites on membrane surfaces, displacing adventitious iron thereby inhibiting lipid peroxidation (the pull and push mechanism) (Chevion, 1991). Moreover, the suggested effect of zinc in inducing the SH-rich MT synthesis my preserve the SH-residue in many functional proteins. Therefore, $\mathrm{Zn}$ may preserve the structural and functional 
integrity of the SH-dependent enzymes including those regulating glucose metabolism. More recently, St Croix et al. (2002) hypothesized that MT which is cysteine-rich, plays a role in $\mathrm{NO}$ signaling events via sequestration or release of $\mathrm{Zn}^{+2}$ by the unique thiolate clusters of the protein. This effect is of special significance since it may help to manage the vascular damage which is one of the major serious complications of diabetes. It has been established that common vascular disease states including diabetes, hypertension and atherosclerosis are associated with endothelial dysfunction, characterized by reduced bioactivity of NO (Channon and Guzik, 2002).

The diminished availability of glucose to the cells of alloxan diabetic rats could eventually lead to the impairment of energy conservation from carbohydrates. The current data are in support to this notion. Alloxan treatment induced a significant increase in creatinine, urea and BUN concentra tions 24 hours after treatment. Alloxan intoxication appears to cause impair ment in the primary energy-forming pathway. The early serious impairment of energy conservation from carbohy drate causes the utilization of protein with the consequent increase in urea and BUN. Accelerated glycolysis and brea kdown of creatine phosphate are the metabolic consequences of the activation of a backup system for the generation of ATP, when the primary energy forming pathways are impaired (Lehnenger, 1970). The marked decrease in the urea and BUN observed 48 hours after alloxan treatment may reflect protein degradation in the treated rats, which may result in the decrease of the mass of active tissue. These deleterious changes may reflect some of the serious consequences of GSH depletion induced by alloxan, which may include the impairment of the different metabolic and synthetic processes. The probable protection of $\mathrm{Zn}$ on the protein manufacturing machinery could probably be mediated by the following mechanisms: a. the protection of the microsomal membranes against the lipid peroxide ative damage. $b$. maintenance of the redox potential of the cells through the restoration of the GSH levels that were reduced due to alloxan treatment. This phase of $\mathrm{Zn}$ protection is probably reflected in the inhibition of the sharp decline in urea and BUN in alloxan plus $\mathrm{Zn}$-treated rats when compared with alloxan-treated rats.

The antiglycogenolytic effect of insulin could be mediated through its stimulation of glycogen syntetase and inhibition of glycogen phosphorylase (Guyton, 1991). The current data reveal that alloxan has a glycogenolytic effect as evidenced by severe depletion of liver glycogen that was seen 48 and 72 hours after alloxan treatment. However, a significant increase in liver glycogen was shown 24 hours following alloxan treatment. It is noticed that the increase and decrease in liver glycogen in alloxan - treated rats goes parallel with the increase and the decrease in serum insulin in the same rats. It can be suggested that the hyperisulinimia that was observed 24 hours after alloxan administration, induces over stimulation of glycogen phsporylase and the suggested alloxan-induced insulin resistance may affect pathways other than those affecting the glycogen metabolizing enzymes.

Additional studies are required to determine the benefits of $\mathrm{Zn}$ treatments that may interrupt the pathogenic cascade induced by alloxan at various points. This may open prospects for the possible involvement of $\mathrm{Zn}$ in therapeutic strategies that aim to 
interrupt the stress sensitive pathways mediating diabetic complications like nephropathy, retinopathy, and cardiovascular damage.

\section{References}

1. Ader, M., Richey, J.M. and Bergman, R.N. (1998). Evidence for direct action of alloxan to induce insulin resistance at the cellular level. Diabetologia 41(11):1327-1336.

2. Altomare, E.; Grattagliano, I.; Vendemaile, G.; Micelli-Ferrari, T. and Signorile, A. (1997): Oxidative protein damage in human diabetic eye. Evidence of a retinal participation. Eur. J. Clin. Invest. 27(2): 141-147.

3. Agardh, C.D.; Stenram, U.; Torffvit, O.; Agardh, E. (2002): Effects of inhibition of glycation and oxidative stress on the development of diabetic nephropathy in rats. J Diabetes Complications 16(6):395-400.

4. Agarwal, R. (2002): Proinflammatory effects of Oxidative Stress in Chronic Kidney Disease: Role of Additional Angiotensin II Blockade. Am. J. Physiol. Renal Physiol (27): [epub ahead of print].

5. Ayaz M, Can B, Ozdemir S, Turan B. (2002): Protective effect of selenium treatment on diabetes-induced myocar dial structural alterations. Biol. Trace Elem. Res. 89(3): 215-26.

6. Barnes, P.J.; Karin, M. (1997): Nuclear factor -KappaB: a pivotal transcription factor inchronic inflammatory diseases. N. Engl. J. Med. (336): 1066-1071.

7. Bakker, S.J.; Ijzeerman, R.G.; Teerlink T.; Westerhoff, H.V.; Gans, and Heine, R.J. (2000): Cytosolic trigycerides and oxidative stress in central obesity: the missing link between excessive artherosclerosis, endothelial dysfunction, and beta-cell failure? Atherosclerosis (148): 17-21.

8. Boden, G.; Chen, X.; Ruiz, j. White J.V. and Rossetti L. (1994): Mechanisms of fatty acid-induced inhibition of glucose uptake. J. Clin.Invest. (93):2438-2446.
9. Brownlee, M. (2001): Biochemistry and molecular cell biology of diabetic complications. Nature (414): 813-820.

10. Buko, V.; Lukivskaya, O.; Nikitin, V.; Taraso, Y.; Zavodnik, L.; Borodinisky, A.; Gorenshlein, B. and Janz, B. (1996). Hepatic and pancreatic effects of polyenolphosphatidylcholine in rats with alloxan-induced diabetes. Cell Biochem. Funct. 14(2): 131-137.

11. Channon, K. M. and Guzik, T.J. (2002): Mechanisms of superoxide production in human blood vessels: relationship to endothelial dysfunction, clinical and genetic risk factors. $J$ Physiol. Pharmacol. 53(4 Pt 1): 515-24.

12. Chevion, M. (1991): Protection against free radical-induced and transition metat-mediated damage: the use of "pull" and "push" mechanisms. Free Rad. Res.Commun. (12): 691-696.

13. DeFronzo, R.A. (1997): pathogenesis of type 2 diabetes: metabolic and molecular implications for identifying diabetes genes. Diabetes Review (5): 177-269.

14. Elbrink, J. and Bihler, I. (1975). Membrane transport: Its relation to basal metabolic rate. Science (188): 117-118.

15. Evans, J.L.; Goldfine, I.D.; Maddux, B.A. and Grodsky, G.M. (2003): Are oxidative stress-activated signaling pathways mediators of insulin resistance and -cell dysfunctions. B-cell dysfunction?. Diabetes 52(1): 1-8.

16. Guyton, A.C. (1991): Insulin, glucagon and diabetes mellitus. In: Text Book of Medical Physiology. Edited by Wonsiewicz, M.J. and Hallowell, R. Saunders., Philadelphia, PA. W.S., PP 855-866.

17. Hanna, P.M.; Kaiiska, M.B.; Jordan S.J.; and Mason, R.P. (1993): Role of metallothionine in zinc (II) and Chromium (III) mediated tolerance to carbon tetrachloride hepatotoxicity: evidence against a trichloromethyl radical-scavenging mechanism. Chem. Res. Toxicol. 6(5): 711-717.

18. Hazleton, G.A.; and Llang, C.A. (1983): Glutathione biosynthesis in the aging adult yellow-fever mosquito 
[Aedes aegypti (Lousisville)]. Biochem. J. (210): 289-295.

19. Kocic, G.; Djordjevic, V.; Vlahovic, P.; Kocic, R.; Pavlovic, D. and Jevtovic, T. (2002): Antioxidants modulate adenosine metabolism in rat mesangial cells cultured under high glucose conditions. Ren. Fail. 24(6): 691-701

20. Koya, D. and King, G.L. (1998): Protein kinase $\mathrm{C}$ and the development of diabetic complications. Diabetes (47): 859-866.

21. Kyriakis, J.M. and Avruch, J. (1996): Sounding he alarm: protein kinase cascades activated by stress and inflammation. J. Biol. Chem. (271): 24313-24316.

22. Lehnenger, A.L. (1970): Contractile and motile systems. In: Bbiochemistry. Edited by Worth. Worth Publisher Inc. New York. N.Y. PP. 583-604.

23. Marshall, S.; Garvey, W.T. and Traxinger R.R. (1991): New insights into the metabolic regulation of insulin action and insulin resistance: role of glucose andamino acids. FASEB J. (5): 3031-3036.

24. McDowell, T.S.; Hajduczok, G.; Abboud, F.M.; and Chapleau, M.W. (1994): Baroreflex dysfunction in diabetes millets II. Site of baroreflex impairment in diabetic rabbits. Am. $J$ Physiol. 266(1pt 2): $\mathrm{H} 244-249$.

25. Mizushige, K.; Tsuji, T. and Noma, T. (2002): Pioglitazone: cardiovascular effects in prediabetic patients. Cardiovasc Drug Rev Winter. 20(4): 329-40.

26. Moustafa, S.A. (1998): Effect of glutathione depletion on carbohydrate metabolism in the rat. Res. Commun. Pathol. Toxicol. (3): 55-64.

27. Moustafa, S.A. (2001): Effect of glutathione (GSH) depletion on the serum levels of triiodothyronine $\left(\mathrm{T}_{3}\right)$, thyroxine $\left(\mathrm{T}_{4}\right)$ and $\mathrm{T}_{3} / \mathrm{T}_{4}$ ratio. Possible protection with zinc. International $J$. Toxicol. 20(1), 15-20. This paper has been presented at the American Physiological Society meeting (Experimental Biology 2000), 15-18 April, 2000, San Diego California, USA.
28. Moustafa, S.A. (2003): Possible protection of the retina with zinc in alloxan- diabetic rats. J. Egept. Ger. Soc. Zool.

29. Moustafa, S.A.; Webster, J.E.; and Mattar, F.E. (1995): Effects of aging and antioxidants on glucose transport in rat adipocytes. Gerontology, (41): 301307.

30. Moustafa, S.A.; Nabil, Z. I and Ahmed, S.H. (2000): Protective effects of zinc against cadmium chloride cytotoxicity in the rat. Res.Commun. Pharmacol. Toxicol. (5): 205-220.

31. Mychka, V.B.; Gornostaev, V.V. and Chazova, I.E. (2002): Cardiovascular complications of type 2 diabetes. Kardiologiia 42(4): 73-77.

32. Nadler, J.L. and Natarajan, R. (2000): Oxidative stress, inflammation and diabetic compliation. In Diabetes Mellitus: A fudamental and Clinical Text. LeRoith D.; Taylor SI, Olefsky JM Eds. Philadelphia, Lippincott Williams \& Wilkins, P. 1008-1016.

33. Nishikawa, T.; Edelstein, D. and Brownlee, M. (2000): The missing link: a single unifying mechanism for diabetic complications. Kidney Int. (58): 26-3

34. Oh-Ishi, M.; Ueno, T. and Maeda, T. (2003): Proteomic method detects oxidatively induced protein carbonyls in muscles of a diabetes model Otsuka Long-evans Tokushima Fatty (OLETF) rat. Free Radic. Biol. Med. 34(1): 1122.

35. Paolisso, G.; Di Maro, G.; Pizza, G.; D'Amore A; Sgambato, S.; Tesauro, P. (1992): Plasma GSH/GSSG affects glcose homeostasis in healthy subjects and non-insulin-dependent diabetes. Am. J. Physiol. (263): E35-E440.

36. Provinciali, M.; Donnini, A.; Argentati, K.; Di Stasio, G.; Bartozzi, B. and Bernardini (2002): Reactive oxygen species modulate $\mathrm{Zn}(2+)$ induced apoptosis in cancer cells. Free Radic. Bio.1 Med.32(5):431-445.

37. Ramana, K.V.; Friedrich, B.; Bhatnagar, A. and Srivastava, S.K. (2002): Aldose reductase mediates cytotoxic signals of hyperglycemia and 
TNF-alpha in human lens epithelial cells. FASEB J. (17): [epub ahead of print].

38. Roe, J.H. (1955): The determination of sugar in blood and spinal fluid with anthrone reagent. J. Biol. Chem. (212): 335.

39. Rosen, P.; Nawroth, P.P.; King, G.; Moller, W.; Tritchler, H.J. and Packer, I. (2001): Th role of oxidative stress in the onset and progression of diabetes and its complications : a summary of a Congress Series sponsored by UNESCO-MCBN, the American Diabetes Association and the German Diabetes Society. Diabetes Metab. Res. Rev. (17): 189-212.

40. Rudolf, E.; Peychl, J.; Radocha, J. and Cervinka, M. (2001): Zinc and its role in the regulation of cell death. Cesk. Fysiol. 50(4): 201-210.

41. Sakurai, K. and Osigo, T. (1994): Generation of alloxan radical in rat islet cells participation of NADPH cytochrome P-450 reductase. Biol. Pharm. Bull. 17(11): 1451-1455.

42. Schmeichel, A.M.; Schmelzer, J.D. and Low, P.A. (2003): Oxidative injury and apoptosis of dorsal root ganglion neurons in chronic experimental diabetic neuropathy. Diabetes 52(1):165-71.

43. Schleicher, E.D. and Weiger, C. (2000): Role of the hexosamine biosynthetic pathway in diabetic nephropathy. Kidney Int. 58 (Suppl. 77): S13-S18.

44. Sempoux, C.; Guitot, Y. Dubois, D. Moulin, p.; and Rahier, j. (2001): Human type 2 diabetes: morphological evidence for abnormal $\beta$-cell function. Diabetes (50):S172-S177.

45. St, Croix, C.M.; Wasserloos, K.J.; Dineley, K.E.; Reynolds; I., Levitan, E.S. and Pitt, B.R (2002): Nitric oxide-induced changes in intracellular zinc homeostasis are mediated by metallothionein/thionein. Am. $J$. Physiol. Lung. Cell. Mol .Physiol. 282(2): L183-L184.

46. Stefek, M. and Tmkova, Z. (1996): The pyridoindole antioxidant stobadine prevents alloxan-induced lipid proxidation by inhibiting its propagation. Pharmacol. Toxicol. 78(2): 77-81.

47. Suntres, Z.E. and Lui, E.M.K. (1990): Biochemical mechanism of metallothionein-carbon tetrachloride interaction in vitro. Biochem. Pharmacol. (39): 833-840.

48. Thomas, J.P.; Bachowski G.J. and Girotti, A.W. (1986): Inhibition of cell membrane lipid peroxidation by cadmium and zinc metallothionine. Biochem. Biophys. Acta. (884): 448461.

49. Thornalley, P.J. and Vasak, M. (1985): Possible role of metallothionein in protection against radiation-induced oxidative stress. Kinetics and mechanisms of its reaction with superoxide and hydroxyl radicals. Biochim. Biophys. Acta. (827): 36-44.

50. Tieze, F. (1969): Enzymic method for quantitative determination of nanogram amounts of total and oxidized glutathione. Applications to mammalian blood and other tissues. Anal. Biochem. (27): 502-522.

51. Varvarovska, J.; Racek, J.; Stozicky, F.; Soucek ,J.; Trefil, L. and Pomahacova, R. (2003): Parameters of oxidative stress in children with Type 1 diabetes mellitus and their relatives. J. Diabetes Complications. 17(1): 7-10.

52. West, I.C. (2000): Radicals and oxidative stress in diabetes. Diabet. Md. (17): 171-180. 


\section{التأثيرات السامة للألوكسان في الجرذان. الآلية والحماية بالزنك}

\section{سهير عبد الله مصطقى \\ قسم علم الحيوان, كلية العلوم, جامعة قناة السويس, الإسماعيلية, مصر مصر}

في الدر اسة الحالية تم إحداث مرض السكر في ذكور الجرذان البيضـاء

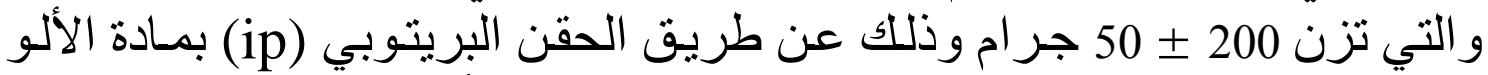

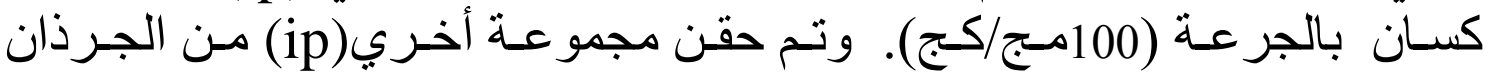

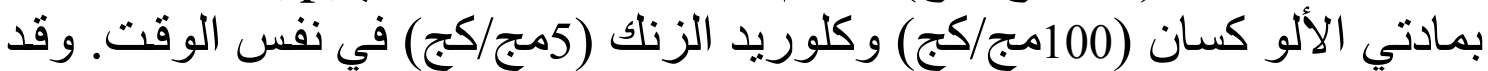

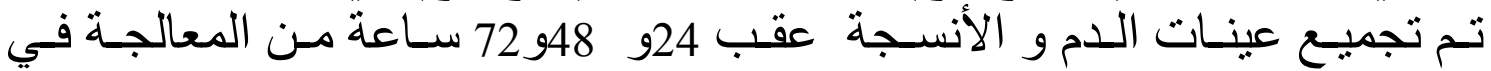

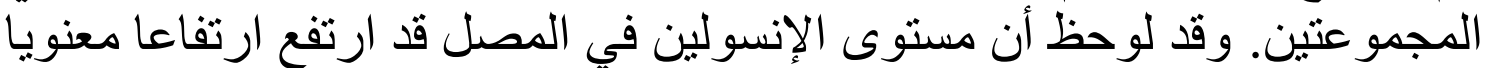

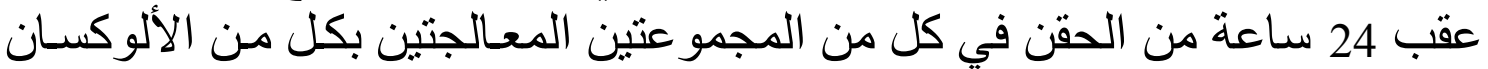

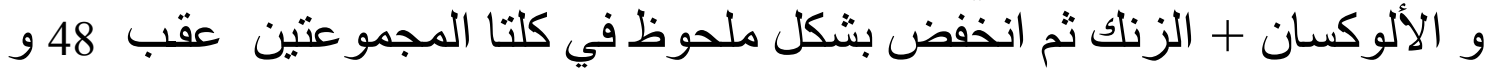

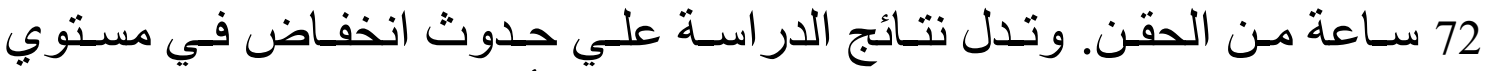

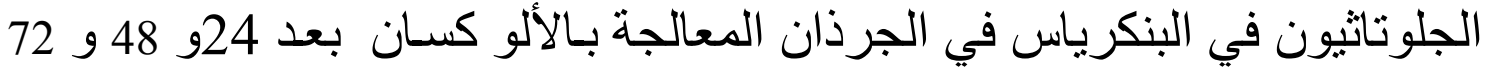

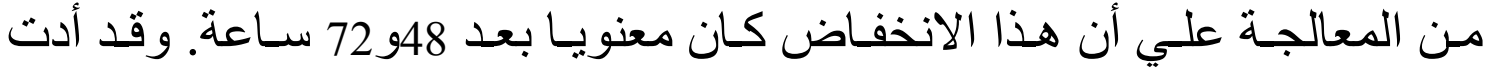

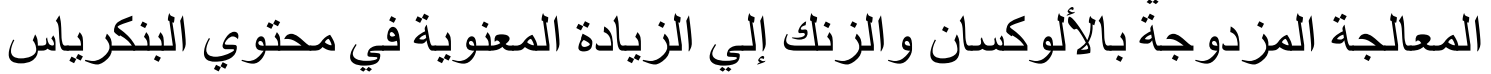

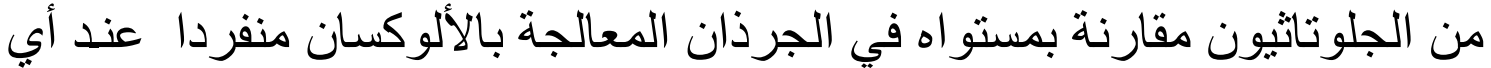

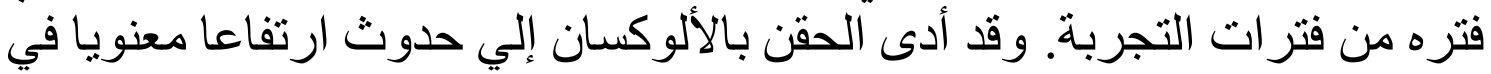

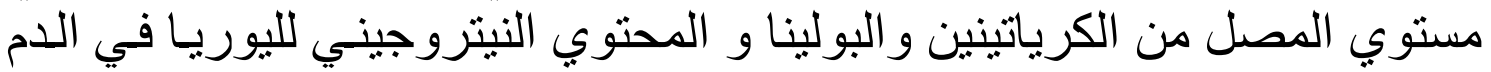

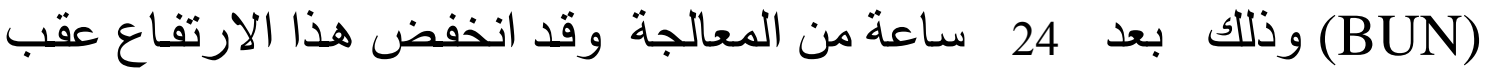

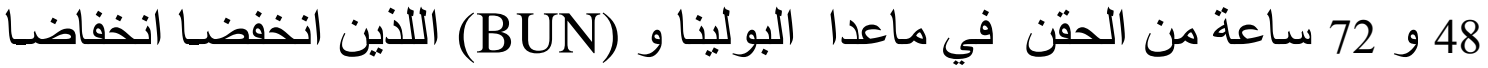

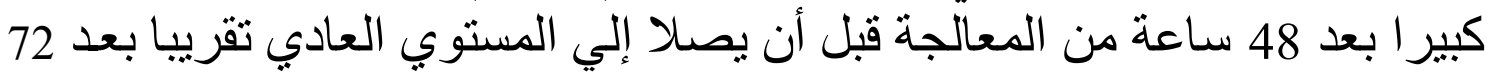

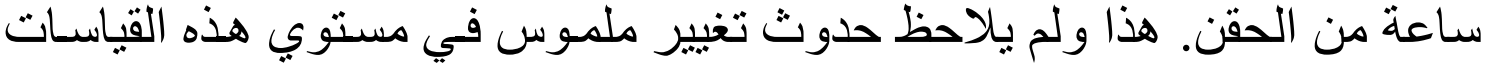

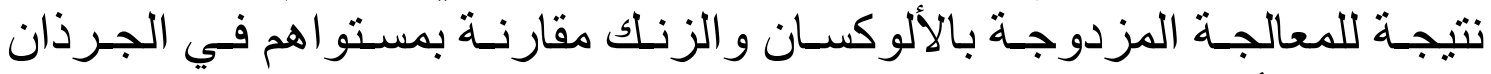

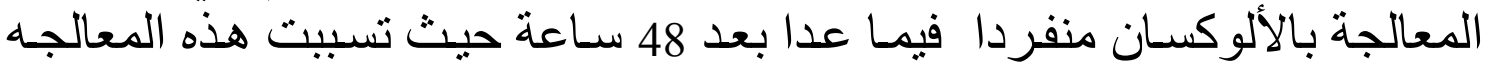

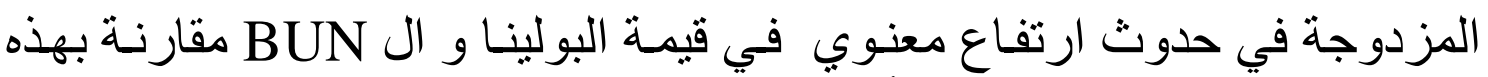

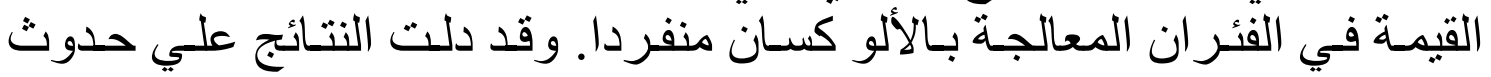

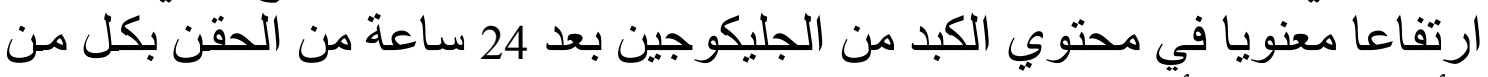

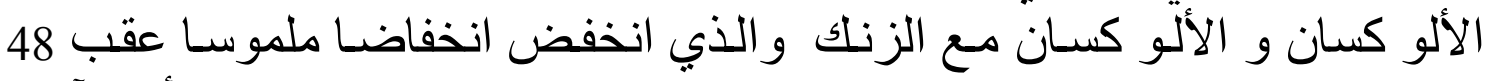

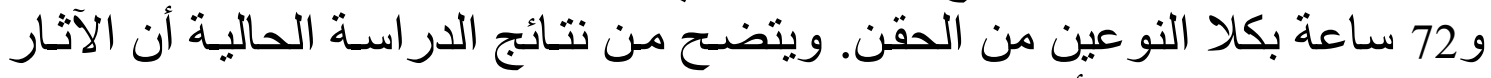

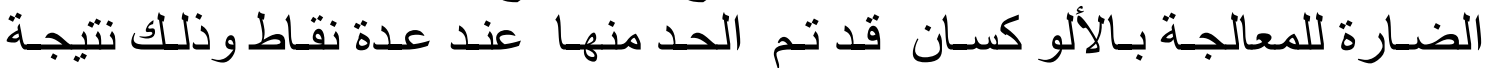




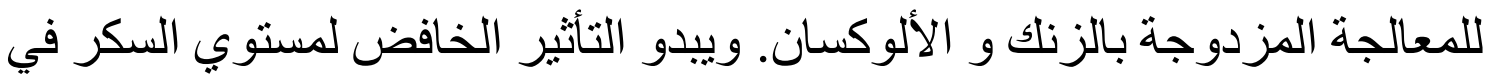

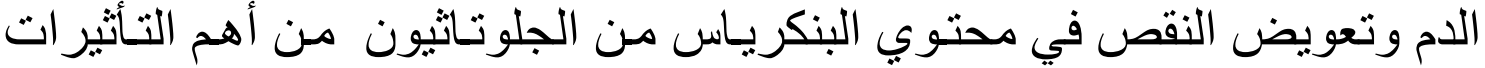
التعويضية للمعالجة بالزنك. 